\title{
ANALYSES OF FUEL BURNUP CALCULATIONS OF KARTINI REACTOR BASED ON THE NEW CALCULATION SCHEME
}

\section{ANALISIS PERHITUNGAN BURN UP BAHAN BAKAR REAKTOR KARTINI BERDASARKAN SKEMA PERHITUNGAN BARU}

\author{
Tegas Sutondo \\ Center of Accellerator's Science and Technology (CAST), BATAN \\ JL. Babarsari, Post Box 6101 ykbb, Yogyakarta 55281 \\ e-mail : tegas@batan.go.id; tegas_s@yahoo.com
}

Received 13 June 2014, received in revised form 11 July 2014, accepted 14 July 2014

\begin{abstract}
ANALYSES OF FUEL BURNUP CALCULATIONS OF KARTINI REACTOR BASED ON THE NEW CALCULATION SCHEME. It has been described a new scheme of fuel burnup calculation, intended to improve the present practice used at Kartini reactor. The improvement includes the use of power distributions, which will be used as the base for estimating the burnup of each individual fuel element, and the inclusion of epithermal neutron which will affect to the burnup rates and the total fuel consumed. A small computation program was then made to perform calculations based on the two calculation schemes, and to see the differences. The results indicate that the proposed scheme results in higher estimated value against that of the present scheme, and the differences tends to increase linearly with the cumulative burnups. For each cumulative burnup of 30 MWD the difference could reach about $9.87 \%$ which is around 3.7 gram for the whole core. It can be concluded that the proposed approach could improve the present's practice of burnup estimation, especially for each individual fuel element which is important to the in-core fuel management program.
\end{abstract}

Keywords : Analyses, Nuclear fuel, Burnup, Calculations, Kartini Reactor, Scheme.

\section{ABSTRAK}

ANALISIS PERHITUNGAN BURNUP BAHAN BAKAR REAKTOR KARTINI BERDASARKAN SKEMA PERHITUNGAN BARU. Diuraikan suatu skema baru dalam perhitungan burnup, yang dimaksudkan untuk memperbaiki model peritungan yang digunakan pada reaktor Kartini saat ini. Penyempurnaan tersebut termasuk penggunaan distribusi daya, yang akan digunakan sebagai dasar dalam memperkirakan nilai burnup untuk setiap elemen bahan bakar, dan penyertaan neutron epitermal yang berpengaruh terhadap laju burnup dan total bahan bakar yang dikonsumsi. Suatu program perhitungan kecil telah dibuat untuk melakukan perhitungan berdasarkan kedua skema perhitungan tersebut, untuk melihat perbedaannya. Hasil perhitungan menunjukkan bahwa skema peritungan yang diusulkan memberikan hasil estimasi yang lebih tinggi terhadap yang diperoleh dengan skema yang digunakan saat ini, dan cenderung naik secara linear dengan meningkatnya nilai burnup. Untuk setiap total burnup sebesar $30 \mathrm{MWD}$, perbedaan tersebut dapat mencapai sekitar 9,87 \% atau sekitar 3,7 gram untuk seluru teras. Disimpulkan bahwa model pendekatan ini dapat memperbaiki model perhitungan yang digunakan saat ini, khususnya dalam memperkirakan nilai burnup untuk setiap elemen bahan bakar, yang penting dalam program pengelolaan bahan bakar selama berada di dalam teras.

Kata Kunci : Analisis, Perhitungan, Burnup, Bahan bakar, Reaktor Kartini, Skema.

\section{INTRODUCTION}

Kartini reactor core, which originally used in Bandung's TRIGA mark II reactor, was designed to operate for a nominal power of $250 \mathrm{~kW}$. It was then moved to Yogyakarta along with the irradiated fuels, which was then to be renamed as Kartini reactor. The reactor was then operated with the nominal power of $100 \mathrm{~kW}$ which considered to be more suitable for the purpose of it functional applications. For some period time after its first criticality in January 1979 the reactor was operated using the irradiated TRIGA fuels of 102 type (using Al as the clad), and then they 
were replaced by the newer type of TRIGA fuel, using SS as fuel clad i.e. of 104 type and some instrumented fuel elements (204 type ). The replacement with new fuel type was completed by mid of 1994s, and the reactor was then operated mainly for education and research services.

One of the important things to do in reactor operation is to keep the core excess of reactivity within the specified range. This was performed by means of fuel shuffling, based on the estimated burnup value of each individual fuel element, in order to have an optimum core pattern. The burnup rate of the fuels might differ greatly across the core, depending on the content of fissile material and neutron flux distribution characteristics in the fuels. Therefore the better estimation of the fuel burnups would help improve the in-core fuel management work and the fuel utilization as well.

This paper was made in conjunction with the above concern i.e. to improve the calculation scheme that used presently, especially in estimating the burnup of individual fuel element, which is important to the in-core fuel management activity.

\section{METHODOLOGY}

As a reactor is operated, atoms and hence the mass of fissile nuclide e.g. U235 in the fuel are continuously depleted, as the results of reaction processes with neutrons, which include fission reaction and capture reaction. The depletion rate is directly proportional to the reaction rate $(R)$ as represented in equation (1)

$$
R=N\left(\sigma_{f}+\sigma_{c}\right) \phi
$$

where

$N=$ atomic density of the fissile material

$\sigma_{f}$ and $\sigma_{\mathrm{c}}$ consecutively are the microscopic cross sections for fission and capture reactions of the fissile material used.

$\phi=$ neutron flux

The depletion of fissile material caused by fission reaction is often referred as burnup that directly corresponds to the amount of energy generated by the fissile material in reactor. There are several units commonly used to measure the cumulative burnup such as:

1. Ratio of atoms or mass of fissile material depleted to their initial amount (\%).

2. Amount of fissile material depleted (gram)

3. Total energy generated (MWD) or

4. Megawatt days per metric ton (MWD/t) of the heavy metal originally contained in the fuel, etc.

In this respect, the burnup $(B)$ can be presented as an equation (2) representing the cumulative energy generated $(Q)$ for any duration time of reactor operation $(t)$

$$
B \approx Q=\sum_{t} P(t) \times t
$$

where

$P=$ Reactor power for each time $(t)$ of operation

The burnup value in term of mass of the fissile material depleted (typically $\mathrm{U}^{235}$ ), can be determined by introducing a conversion constant representing the energy generated $(Q)$ by total number of atoms $\left(N^{235}\right)$ per gram of $\mathrm{U}^{235}$, i.e.

$$
\mathrm{Q} / \mathrm{gram} \text { of } \mathrm{U}^{235}=\mathrm{N}^{235} \times \mathrm{E}_{\mathrm{f}}=0,95024 \mathrm{MWD}
$$

or

$$
1 M W D=1,05237 \operatorname{gram}^{235}
$$

where 
$E_{f}=$ average energy generated per fission $\approx 200 \mathrm{MeV}=3.20438 \times 10^{-11}$ watt-s ${ }^{(1)}$

Then by taking account the loss due to capture reactions, the total $U^{235}$ consumed per MWD of energy generated becomes

$$
1 M W D=1,05237\left(\frac{\sigma_{f}+\sigma_{c}}{\sigma_{f}}\right) \quad \operatorname{gram} U^{235}
$$

\section{Present's Practice of Burn up Calculations}

The present burnup calculations practice at Kartini reactor is based on the following steps:

1. Counting the cumulative energy generation $(Q)$ over a period of time $(t)$ based on equation (2) where power levels $(P)$ and the corresponding time of operations $(t)$ are taken from the log book recording data of operating history.

2. The cumulative core burnup in term of gram of $U^{235}$ consumed $\left(B_{c}\right)$ is then calculated by introducing a proportionality factor $(G)=1.25$ gram U ${ }^{125}$ per MWD (2), which included the depletion by capture reactions as expressed by equation (5).

3. The burnup of individual fuel element $\left(B_{\mathrm{el}}\right)$ was then calculated by multiplying the fuel average burnup in the core, with a factor $F_{r}$ representing the ratio of zone's or ring's average power density $\left(\bar{P}_{r}\right)$ to that of core's average $\left(\bar{P}_{\mathrm{c}}\right)$ as presented in equation (6); with $N_{\mathrm{F}}$ represents the total number of fuels in the core.

$$
B_{e l}=\frac{B_{c}}{N_{F}} x F_{r}=\frac{B_{c}}{N_{F}} x \frac{\bar{P}_{r}}{\bar{P}_{c}}
$$

In this case the value of $F_{\mathrm{r}}$ was obtained from the result of criticality calculation using a neutronic code of one dimensional core geometry and two groups of neutron energy.

\section{The Proposed Sheme of Burn up Calculations}

The proposed scheme of burnup calculation is basically quite similar with that used presently, except for the following subjects:

1. The proportionality factor $(G)$ is slightly modified to include the contribution of reactions in the resonance region. Table 1 presents the microscopic cross sections used for this purpose, and based on which, the proportionality factor $(G)$ becomes

$$
G=1.2917 \text { gram per MWD }
$$

This value is slightly higher than the present value of $1.25 \mathrm{~g} / \mathrm{MWD}$, and as the result the consumption rate of $\mathrm{U}^{235}$ will be slightly higher.

Table1. Microscopic Cross Sections of Some Fissile Materials (3).

\begin{tabular}{ccccc}
\hline \multirow{2}{*}{$\begin{array}{c}\text { Fissile } \\
\text { materials }\end{array}$} & \multicolumn{2}{c}{$\begin{array}{c}\text { Average over } \\
\text { thermal spectrum }\end{array}$} & \multicolumn{2}{c}{$\begin{array}{c}\text { Slowing down region } \\
\text { resonance integral }\end{array}$} \\
\cline { 2 - 5 } & $\sigma_{\text {nf }}(\mathbf{b})$ & $\sigma_{\text {ny }}(\mathbf{b})$ & $\sigma_{\text {nf }}(\mathbf{b})$ & $\sigma_{\text {ny }}(\mathbf{b})$ \\
\hline${ }^{233} \mathrm{U}$ & 468.20 & 42.20 & 751.71 & 134.16 \\
\hline${ }^{235} \mathrm{U}$ & $\mathbf{5 0 4 . 8 1}$ & 86.70 & $\mathbf{2 7 1 . 5 3}$ & 131.97 \\
\hline${ }^{239} \mathrm{Pu}$ & 699.34 & 274.32 & 289.36 & 184.06 \\
\hline${ }^{241} \mathrm{Pu}$ & 936.65 & 334.11 & 570.66 & 169.13 \\
\hline
\end{tabular}

2. The burnup distributions of individual fuel element $\left(B_{\mathrm{el}}\right)$, is determined based on the average power generated $P(r, \theta)$ of each fuel element located at any radial or ring of $r$ and angular position of $\boldsymbol{\theta}$, as in equation (8), 
instead of based on the zone's average as used presently. This approach was to take into account some variations of neutron flux distributions in the fuel elements of the same ring, which depends on their angular position.

$$
P_{e l}(r, \theta)=E_{f} \Sigma_{f}^{e l}(r, \theta) \bar{\phi}_{e l}(r, \theta) V_{e l}
$$

where

$$
\begin{array}{ll}
\sum_{\mathrm{f}}^{\mathrm{el}}(\mathrm{r}, \theta) & =\mathrm{N}^{235}(\mathrm{r}, \theta) \sigma_{\mathrm{f}}=\text { macroscopic fission cross section }\left(\mathrm{cm}^{-1}\right) \\
E_{f} & =\text { energy generated per fission reaction (watt) } \\
\mathrm{N}^{235}(\mathrm{r}, \theta) & =\text { atomic density of the } \mathrm{U}^{235}\left(\text { atom } / \mathrm{cm}^{3}\right) \\
\sigma_{f} & =\text { microscopic fission cross section of } \mathrm{U}^{235}\left(\mathrm{~cm}^{2}\right) \\
\bar{\phi}_{\mathrm{el}}(\mathrm{r}, \theta) & =\text { average neutron flux in each individual fuel }\left(\mathrm{n} / \mathrm{cm}^{2}-\mathrm{s}\right) \\
V_{\text {el }} & =\text { fuel active volume per element }\left(\mathrm{cm}^{3}\right)
\end{array}
$$

Hence, the total power generated in the core is the summation of $P_{\mathrm{el}}(r, \theta)$ as presented in equation (9)

$$
P_{T}=\sum_{1}^{N_{e l}} P_{e l}(r, \theta)=E_{f} \bar{\Sigma}_{f} \bar{\phi} V_{T}
$$

with $\bar{\Sigma}_{\mathrm{f}}=$ core average macroscopic fission cross section

$\bar{\phi} \quad=$ core's average neutron flux

$\mathrm{V}_{\mathrm{T}} \quad=\mathrm{N}_{\mathrm{el}} \mathrm{V}_{\mathrm{el}}$ total fuel's volume in the core $\left(\mathrm{cm}^{3}\right)$

$\mathrm{Nel}_{\mathrm{el}} \quad=$ total number of fuel elements in the core or

$$
\bar{\Sigma}_{f}=\frac{\sum_{1}^{N e l} \bar{\Sigma}_{f}(r, \theta)}{N_{e l}} \text { and } \bar{\phi}=\frac{\sum_{1}^{N_{e l}} \bar{\phi}(r, \theta)}{N_{e l}}
$$

The power generated in each fuel element $P_{\mathrm{el}}(r, \theta)$ can then be determined by normalizing to the average power of the fuels loaded in the core i.e. $\overline{\mathrm{P}}_{\mathrm{el}}=\mathrm{P}_{\mathrm{T}} / \mathrm{N}_{\mathrm{el}}$, to get

$$
P_{e l}(r, \theta)=F_{e l}(r, \theta) \bar{P}_{e l}
$$

where

$$
F_{e l}(r, \theta)=\frac{\Sigma_{f}(r, \theta) \bar{\phi}(r, \theta)}{\bar{\Sigma}_{f} \bar{\phi}}=\frac{w(r, \theta) \bar{\phi}(r, \theta)}{\bar{w}_{e l} \bar{\phi}}
$$

is the ratio of fission reaction rate in the fuel located in any position of $(r, \theta)$ to that of the core's average value.

To include the fission reactions for both thermal and epithermal neutrons, equation (12) becomes

$$
\mathrm{F}_{\mathrm{el}}(\mathrm{r}, \theta)=\frac{\mathrm{w}(\mathrm{r}, \theta)\left(\sigma_{\mathrm{f}}^{\text {th }} \bar{\phi}_{\mathrm{th}}(\mathrm{r}, \theta)+\sigma_{\mathrm{f}}^{\mathrm{epi}} \bar{\phi}_{\mathrm{epi}}(\mathrm{r}, \theta)\right)}{\overline{\mathrm{w}}_{\mathrm{el}}\left(\sigma_{\mathrm{f}}^{\text {th }} \bar{\phi}_{\mathrm{th}}+\sigma_{\mathrm{f}}^{\text {epi }} \bar{\phi}_{\mathrm{epi}}\right)}
$$

where

$$
\mathrm{w}(\mathrm{r}, \theta)=\mathrm{w}_{0}(\mathrm{r}, \theta)\left(1-\mathrm{BU}_{\mathrm{el}}(\mathrm{r}, \theta)\right)=\text { current's amount of } \mathrm{U}^{235} \text { contained in the fuel of position }(\mathrm{r}, \theta)
$$

$w_{0}(r, \theta)=$ initial amount of $\mathrm{U}^{235}$ contained in the fuel of position $(r, \theta)$ which can be obtained from the fuel manufacturing data or as listed in the Physical Inventory Listing (4). 
$B U_{\mathrm{e}}(r, \theta)=$ cumulative burnup fraction of the fuel at position $(r, \theta)$, including losses due to capture reaction.

$$
\overline{\mathrm{W}}_{\mathrm{el}}=\text { fuel's average content of } \mathrm{U}^{235}=\frac{\sum_{\mathrm{e} \text { el }} \mathrm{w}(\mathrm{r}, \theta)}{\mathrm{N}_{\mathrm{el}}}
$$

In this work, the average neutron flux of each individual fuel element was determined based on the criticality calculation using a three dimensional reactor model of $\operatorname{MCNP}{ }^{(5)}$. The power generated $P_{\mathrm{el}}(r, \theta)$ and the associated burnup of individual fuel element $B(r, \theta)$ can then be determined by substituting equation (11) into equation (2) and by using equation (7), the total $\mathrm{U}^{235}$ consumed in the fuel can then be determined. For this purpose, a small computation program was made to determine the power distributions of all individual fuel elements for a specified reactor power and the corresponding burnup values for any specified target of cumulative burnup. Figure 1 present the proposed scheme of burnup calculation which optionally can be used to perform calculation based on the present's scheme as well.

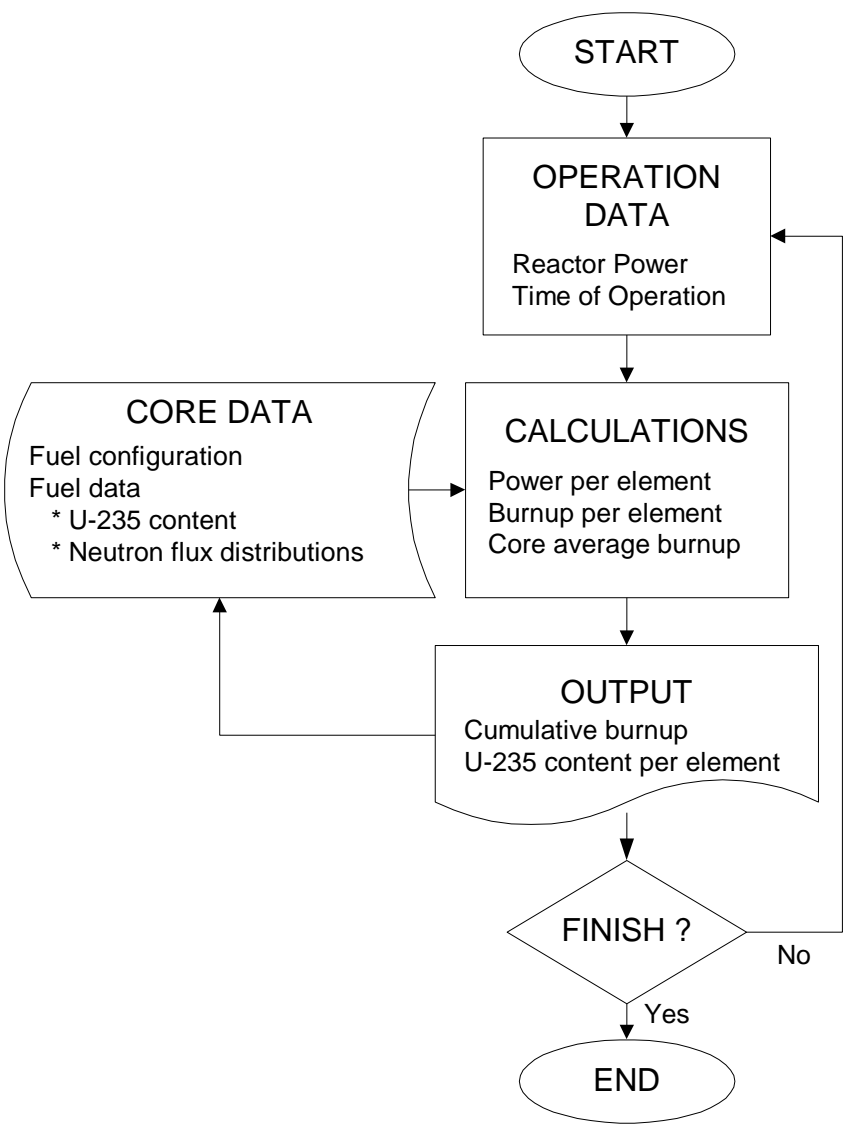

Figure 1. The proposed scheme of burnup calculation.

A module of TRIGA-MCNP (5) was used to model the core condition of Kartini reactor, based on current's core loading patterns ${ }^{(6)}$. In order to simulate the flux distribution shape in the core, close to that of in real operating condition, the control rod withdrawal positions were adjusted similar to that of typical operation at nominal power. Figure 2 present the current's core configuration which contains some 69 fuel elements distributed within the annular ring of $B$ to $F$. 


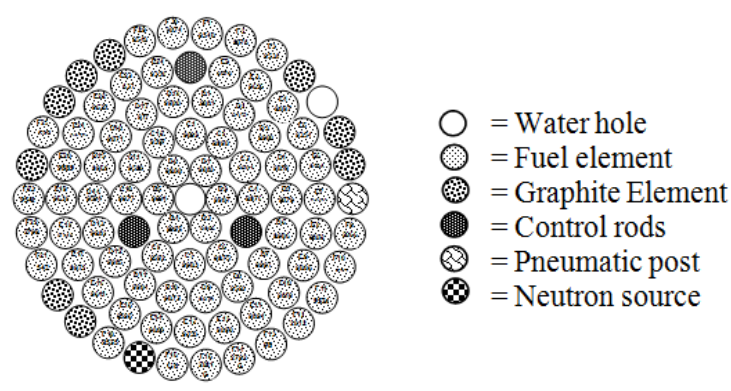

Figure 2. Core configuration of Kartini Reactor (6).

A criticality calculation was then performed using MCNPX ${ }^{(7)}$ with the output tally of average neutron flux of each individual fuel cell. The calculation was to include neutron spectrum of at least the thermal and the epithermal regions. The calculated average neutron fluxes, along with the $U^{235}$ content of individual elements were then used as the base for power and burnup distribution calculations.

Using the prepared computation program, and the data of individual fuel elements, the power distributions of the individual fuel elements can then be determined for any level of reactor power $(P)$. Then in order to define the proper interval of burnup step $(\triangle B U)$ which will be used for further fuel burnup calculation, it was assumed that the reactor was operated everyday at nominal power of $100 \mathrm{~kW}$, for 6 hrs per day and 5 days a week. Based on this operation scheme, the energy generated per week is of $0.125 \mathrm{MWD}$, and this value was then used as reference of $\triangle B U$. Burnup calculations were then performed for a certain target of cumulative burnup for various value of $\triangle B U$ s, to see the deviation of the results to that of the reference value.

Based on the above calculation results, pick the appropriate value of $\triangle B U$ to perform burnup calculations for several burnup steps, based on both the present's calculation scheme that used thermal neutron only, which was then used as reference, and based on the proposed scheme that included both thermal and epithermal neutrons, to see the differences.

\section{RESULTS AND DISCUSSIONS}

\section{Power Distributions}

Calculation of power distributions in each individual fuel element has been performed for a reactor power of $100 \mathrm{~kW}$. Figure 3, trough 6 show the results of the power distribution for the individual fuels located in ring B, C, D and $E$, respectively, showing some variations within the rings. Such variation also appear for fuels of the remaining ring $F$, and this was caused by both the variations in $\mathrm{U}^{235}$ content and the characteristics of neutron flux in each fuel element. Based on this fact, the burnup rates among the fuels of the same ring might be different as well.

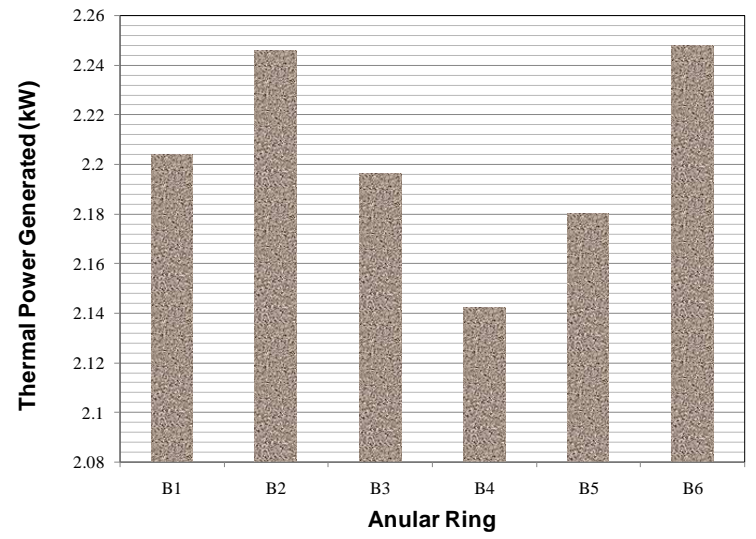

Figure 3. Power distributions in each fuel of ring $B$. 


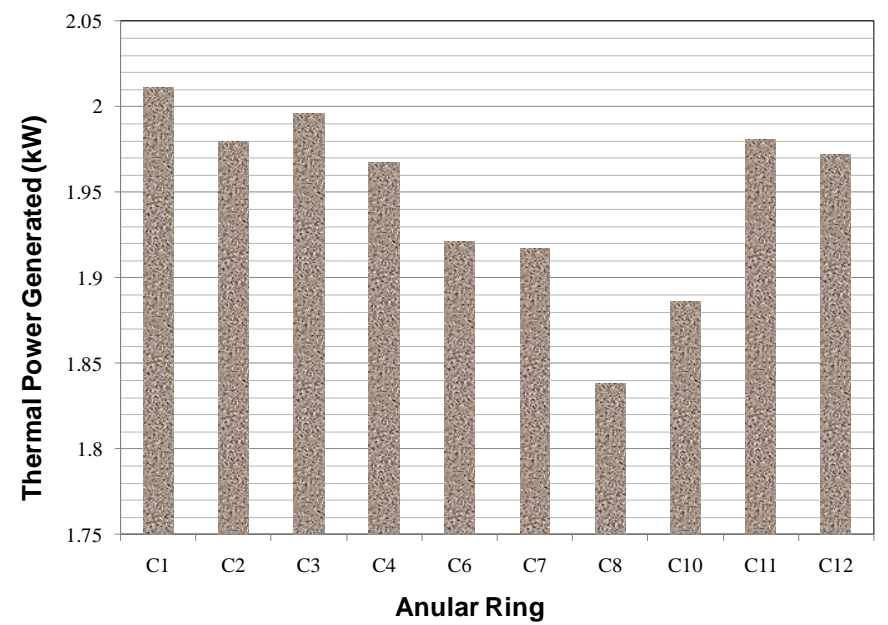

Figure 4. Power distributions in each fuel of ring $C$.

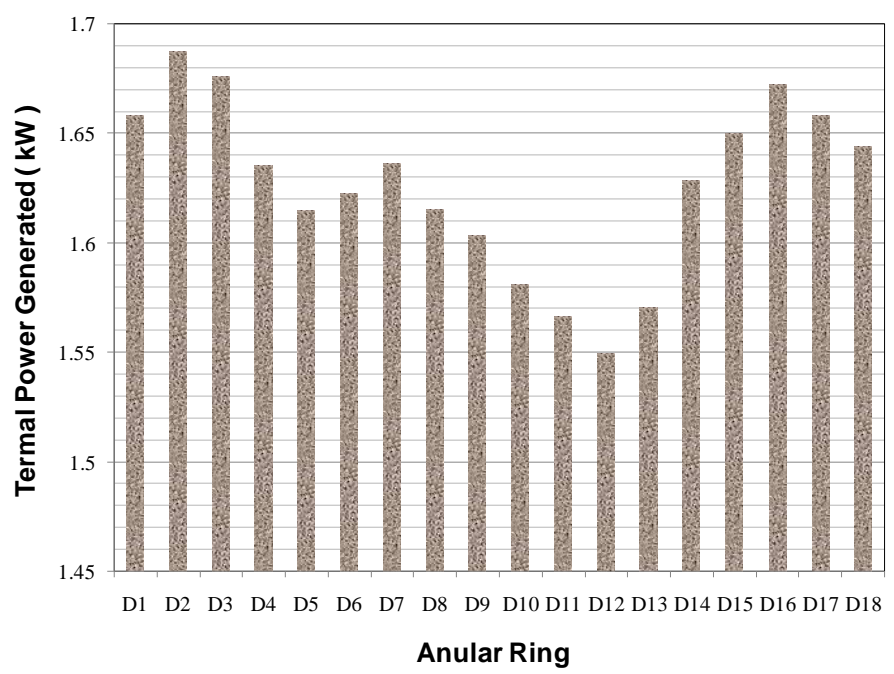

Figure 5. Power distributions in each fuel of ring $D$.

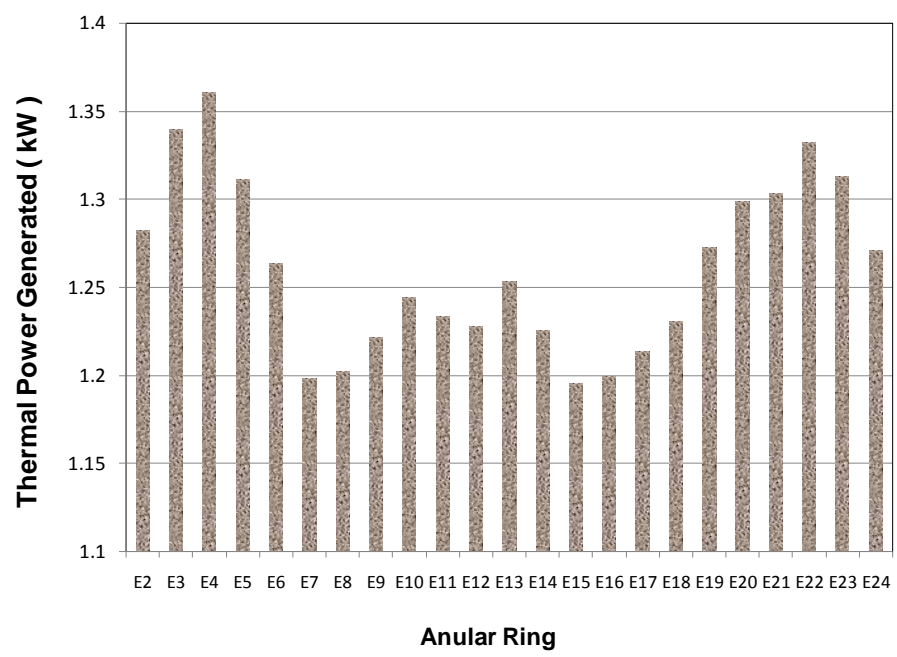

Figure 6. Power distributions in each fuel of ring $\mathrm{E}$. 
Table 2 presents the ring's average power distributions and the associated value for the fuel element, showing that the fuel element of ring B has the highest power density, and decreased toward the outer rings. This is consistent with the radial neutron flux distributions profile in the core as indicated by Figure 7.

Table 2. Power Distributions in the Core for Reactor Power of $100 \mathrm{~kW}$.

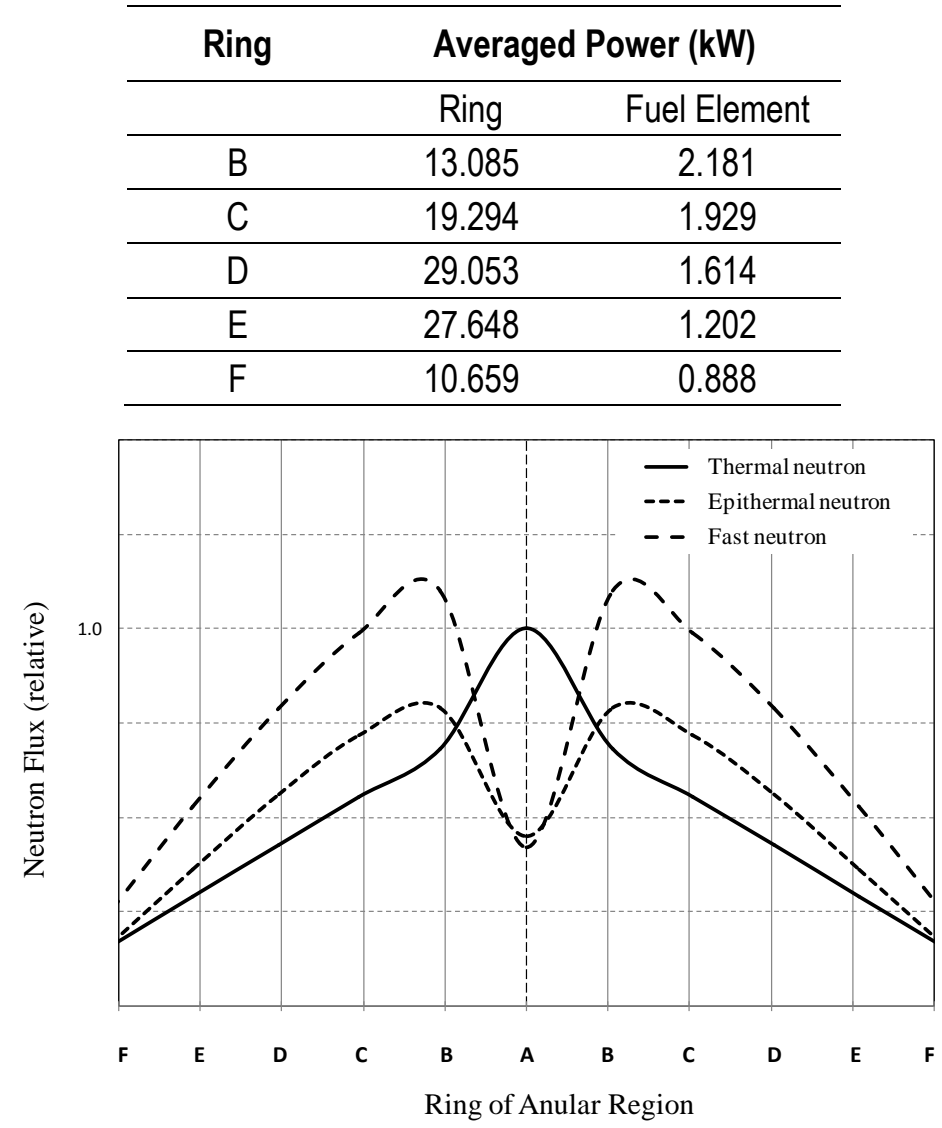

Figure 7. Radial Neutron Flux Profiles.

\section{Burnup Calculations}

In order to find appropriate value of $\triangle B U$ that will be used for further the burnup evaluation, a series calculations had been performed for a certain target of cumulative burnup, using several burnup steps relative to the assumed reference value of $0.125 \mathrm{MWD}$. Figure 8 depicts the deviation of the results for various values of $\triangle B U$ against the reference values, showing a linear trend. The result shows that based on the assumed operating mode, the effect of burnup step to the result of burnup calculation is insignificant. For a $\triangle B U$ of $6 \mathrm{MWD}$, which is equivalent to 12 month-period of reactor operations, the deviation to the reference value is still reasonably low, i.e. of around $0.15 \%$. The deviation in fact would be much lower, since the reactor in reality was not operated every day for 5 days a week as assumed in this calculation.

Based on the above results of burnup step evaluation, a $\triangle B U$ of 1.5 MWD was then used to perform burnup calculations based on both the present's scheme, which was used as reference and based on the proposed seheme. Figure 9, presents the differences of total $\mathrm{U}^{235}$ consumed for the whole core against the reference values, for various target of cumulative burnups. The result indicates that the difference increases linearly with the cumulative burnup, and reach around 3.7 gram for a cumulative burnup of $30 \mathrm{MWD}$ which is around $9.87 \%$ over the reference value. 


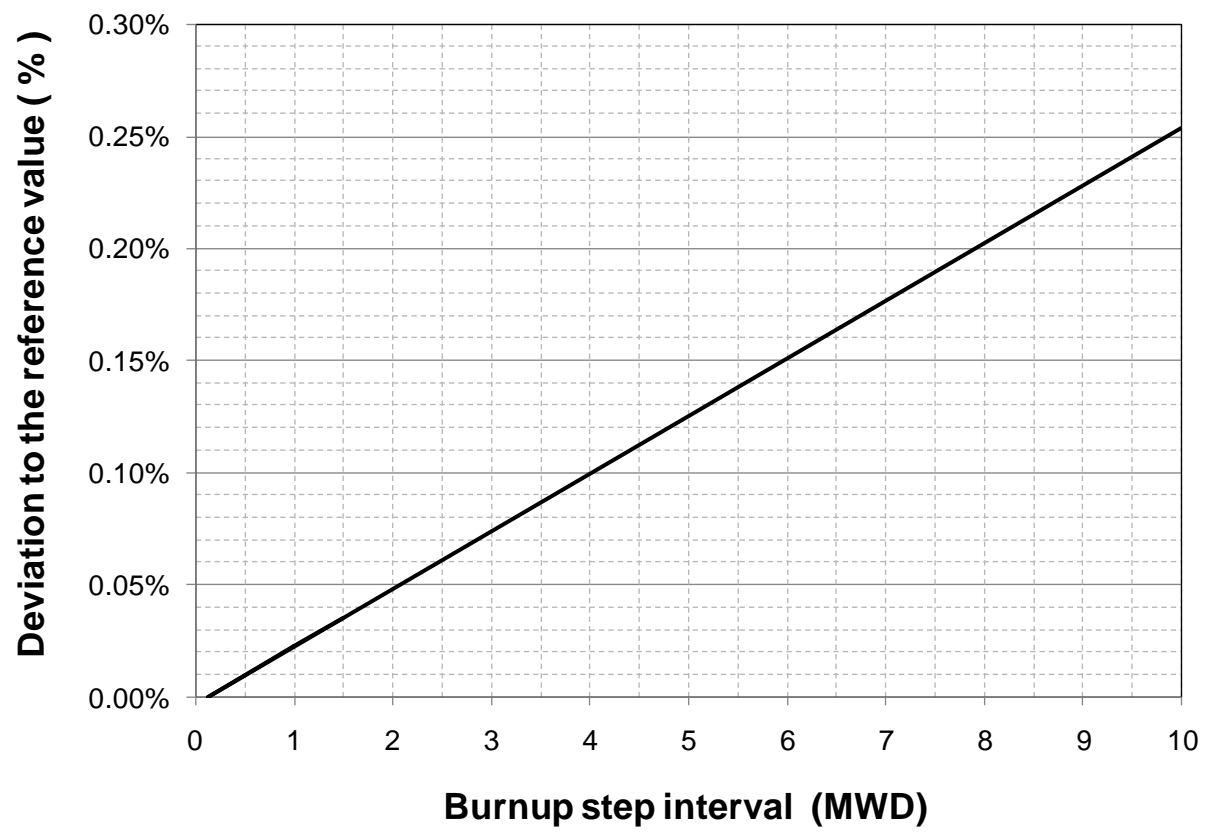

Figure 7. Deviation of burnup calculation results to the reference value as a function of $\triangle B U$.

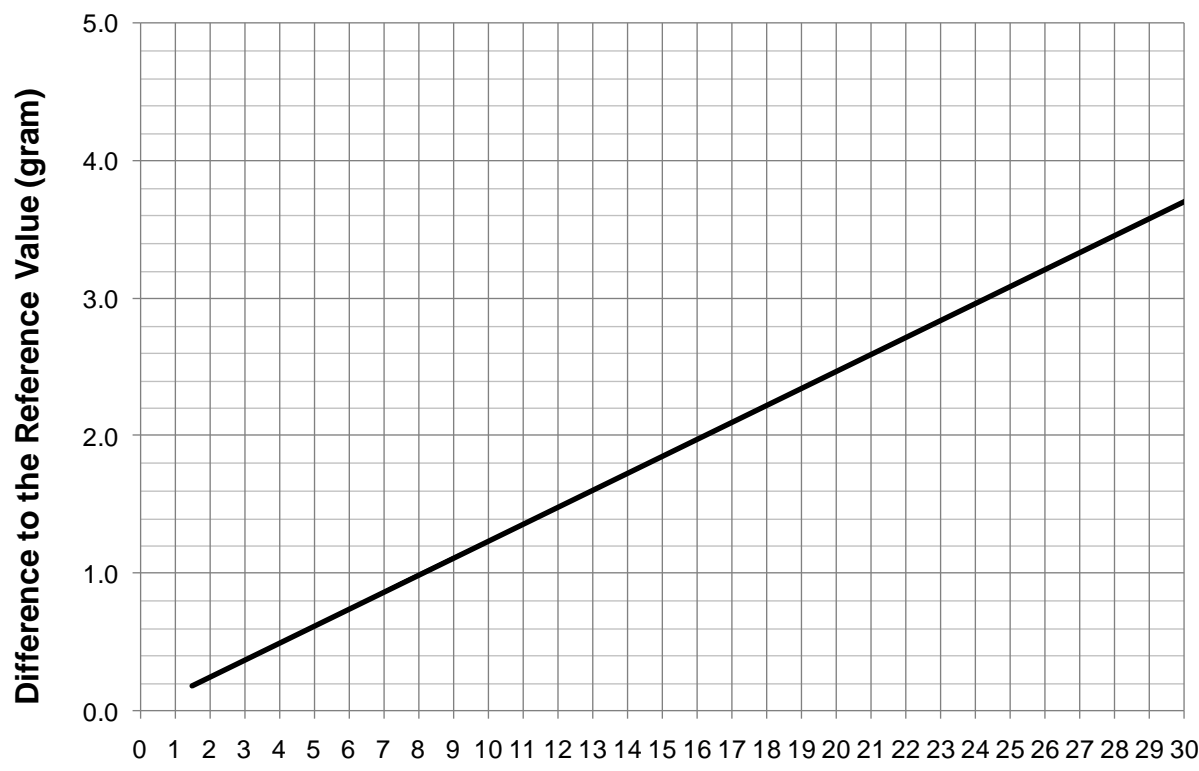

Cumulative Burnup (MWD)

Figure 9. Differences of total $\mathrm{U}^{235}$ consumed for the whole core against the reference values, as a function of cumulative burnup.

The differences to the ring's average burnup, is shown as in Figure 10, where ring $C$ is seen to be the most significant, followed by ring $B$, then ring $D$, ring $E$ and finally ring $F$ being the smallest one. Such characteristics of the differences are as the result of two combining parameters i.e. the relative differences between epithermal and thermal neutrons at each ring and the associated power density (see Figure 6 and Table 2). 


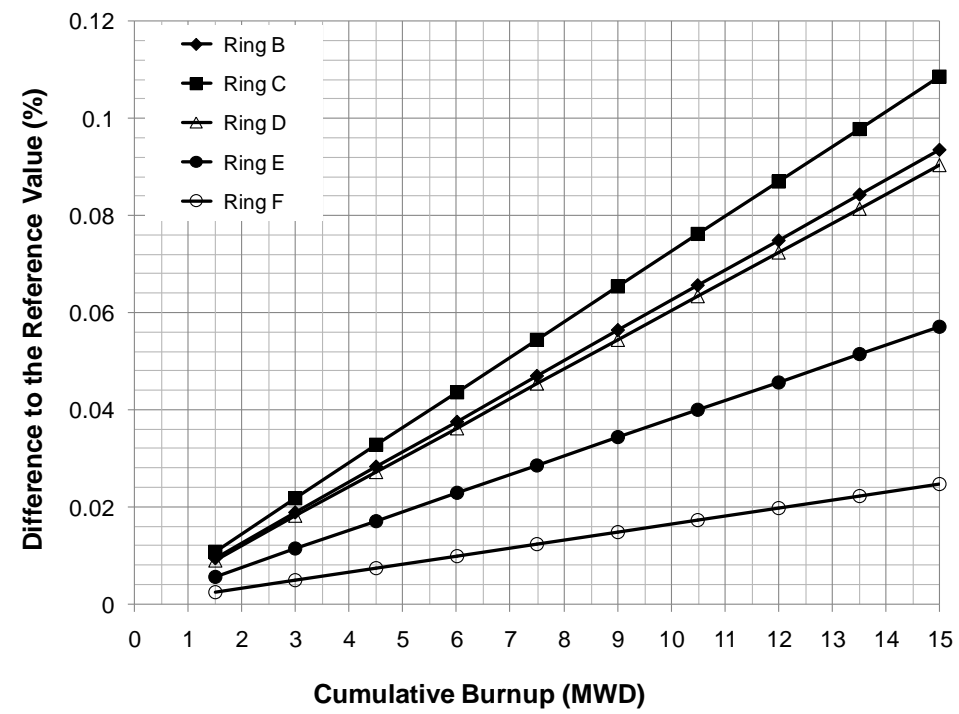

Figure 10. Differences of burnup calculation result to the reference values by ring.

\section{CONCLUSION}

Burnup calculations of Kartini reactor has been exercised based the two schemes of calculation, i.e. the presently used and the proposed calculation schemes. The calculation included the fuel's power distributions by rings and the effect to the burnup rates of each individual fuel element; the sensitivity of burnup step $(\Delta B U)$ to the result of cumulative burnup calculation; and the differences of burnup calculations based on the two schemes as a funtion of cumulative burnup. The results indicate that based on the assumed reactor operating mode, the effect of burnup step is not so significant to the result of calculations. The calculation based on the proposed scheme results in higher estimated value against that of the present scheme, and the differences tends to increase linearly with the cumulative burnups. For the whole core the difference could reach about $9.87 \%$ which is around 3.7 gram over the reference value, for each cumulative burnup of $30 \mathrm{MWD}$. The results conclude that the proposed calculation scheme could improve the present's practice of burnup estimation, especially for each individual fuel element which is important to the in-core fuel management program.

\section{REFERENCES}

1. HDBK-1019/1-93, DOE FUNDAMENTALS HANDBOOK NUCLEAR PHYSICS AND REACTOR THEORY, Volume 1, U.S. Department of Energy. FSC-6910, JANUARY (1993).

2. TRIGA REACTOR CHARACTERISTICS, IAEA Education and Training, Nuclear Installation Safety Division of the IAEA, updated on 18 May (2005)

3. S.F. MUGHABGHAB, Atlas of Neutron Resonances, National Nuclear Data Center, Brookhaven National Laboratory, Published by Elsevier Science, April 17, (2006), http://www.nndc.bnl.gov/atlas/atlasvalues.html, down loaded on March 13, (2014)

4. THE ACCOUNTANCY OF NUCLEAR MATERIALS FOR MBA RI-B, Center for Accelerator and material Process Technology, National Nuclear Energy Agency of Indonesia, Report period June 07, 2011 - May 09, (2014).

5. P. I. YAZID, "TRIGA-MCNP", version 9, January (2006).

6. SAFETY ANALYSES REPORT OF KARTINI REACTOR, revision 7, Center for Accelerator and Material Process Technology, National Nuclear Energy of Indonesia (BATAN), Document No: C7/05/B2/LAK/(2012)

7. D. B. Pelowitz, MCNPXTM USER'S MANUAL, Version 2.6.0, LA-CP-07-1473, April (2008). 